\title{
MODELLING OF ELECTRICAL CHARACTERISTICS OF PHOTOVOLTAIC POWER SUPPLY SOURCES
}

\author{
M. Petkov, D. Markova, St. Platikanov ${ }^{*}$ \\ Technical University of Gabrovo, Faculty of Electrical Engineering and \\ Electronics 4, Hadji Dimitar Str., 5300 Gabrovo, Bulgaria
}

\begin{abstract}
Summary: The photovoltaic (PV) generators are a major element of PV power systems, characterized by a low conversion ratio. This accounts for the necessity to study the current-voltage and power-voltage characteristics of PV sources in order to obtain maximum power output when there are changes both in the modules themselves and in the environment where they operate. In this paper the classical and the modified single-diode models have been used to model the electrical characteristics of PV cells and modules. Mathcad software package has been used for the modelling. The impact of solar radiation, temperature and shading both on electrical characteristics and on the PV cells and modules efficiency has been studied. Copyright (C) 2006 IFAC
\end{abstract}

Keywords: electrical characteristics, single-diode model, modelling, efficiency.

\section{INTRODUCTION}

When photovoltaic conversion is used to produce electric power, the most important condition is to provide maximum efficiency at a lower price. At present the efficiency does not exceed $24 \%$ in laboratory conditions, and $15-18 \%$ up to $20 \%$ in real conditions. Therefore, the modelling of electrical characteristics of PV cells and modules - currentvoltage (I-V) and power-voltage (P-V) is important in order to determine their efficiency.

Figure 1 shows current-voltage and powervoltage characteristics of a PV cell. To evaluate effectiveness of the real PV cell, in addition to the efficiency, the fill factor $(F F)$ is used which shows to what extent the real effectiveness of the cell, $U_{m p} . I_{m p}$ approximates the idealized $U_{o c} . I_{s c}$ :

$F F=\frac{U m p \operatorname{Im} p}{U o c I s c}$,

where:

$U_{m p}$ and $I_{m p}$ are respectively the voltage and current at the maximum power rate point (MPP) - $P_{m p}$;

$U_{o c}$ is the open-circuit voltage at $R_{L}=\infty$;

$I_{s c}$ is the short-circuit current at $R_{L}=0$.

For the real PV cells the fill factor ranges from 0,75 to 0,85 .

\section{PV CELLS MODELING}

\subsection{Classical Single-Diode Model}

The most common mathematical model employed to define the PV cell current-voltage characteristics (direct and reverse) was proposed by Bishop (1988). It is based on the equivalent circuit shown in Figure 2 [1]. The analytical expression of the model is as follows:

$I=I_{p h}-I_{s}\left[\exp \left\{\frac{U+I R_{s}}{m U_{t}}\right\}-1\right]-\frac{U+I R_{s}}{R_{p}}$,

where:

I is the PV cell current $[\mathrm{A}]$;

$\mathrm{I}_{\mathrm{ph}}$ is the photocurrent $[\mathrm{A}]$;

$\mathrm{I}_{\mathrm{S}}$ is the saturation current $[\mathrm{A}]$;

$\mathrm{U}$ is the cell voltage [V];

$\mathrm{R}_{\mathrm{s}}$ is the series resistance [ $\left.\Omega\right]$;

$\mathrm{R}_{\mathrm{p}}$ is the parallel resistance $[\Omega]$;

$\mathrm{m}$ is the diode factor;

$\mathrm{U}_{\mathrm{t}}=\mathrm{kT} / \mathrm{q}$ is the temperature voltage $[\mathrm{V}]$.

Using Mathcad software package, the equation (2) can be transformed so that the PV cell current I can be calculated in the function of its voltage $\mathrm{U}$ and solar radiation $E\left[\mathrm{~W} / \mathrm{m}^{2}\right]$ : 


$$
\begin{aligned}
& I(U, E)=\frac{\left\lfloor-R_{s} U-(A(U, E)) \exp (A(U, E)) m U_{t} R_{p}\right\rfloor}{\left(R_{p}+R_{s}\right) \cdot R_{s}} \\
& -\frac{\left[(A(U, E)) \exp (A(U, E)) m U_{t} R_{s}\right\rfloor}{\left(R_{p}+R_{s}\right) R_{s}} \\
& +\frac{\left\lfloor R_{s} I_{p h}(E) R_{p}+R_{s} I_{s} R_{p}\right\rfloor}{\left(R_{p}+R_{s}\right) R_{s}}
\end{aligned}
$$

where:

$$
A(U, E)=R_{s} I_{s} R_{p} \frac{\exp \left[R_{p} \frac{\left(R_{s} I_{p h}(E)+R_{s} I_{s}+U\right.}{m \cdot U_{t}\left(R_{p}+R_{s}\right)}\right]}{m U_{t}\left(R_{p}+R_{s}\right)}
$$

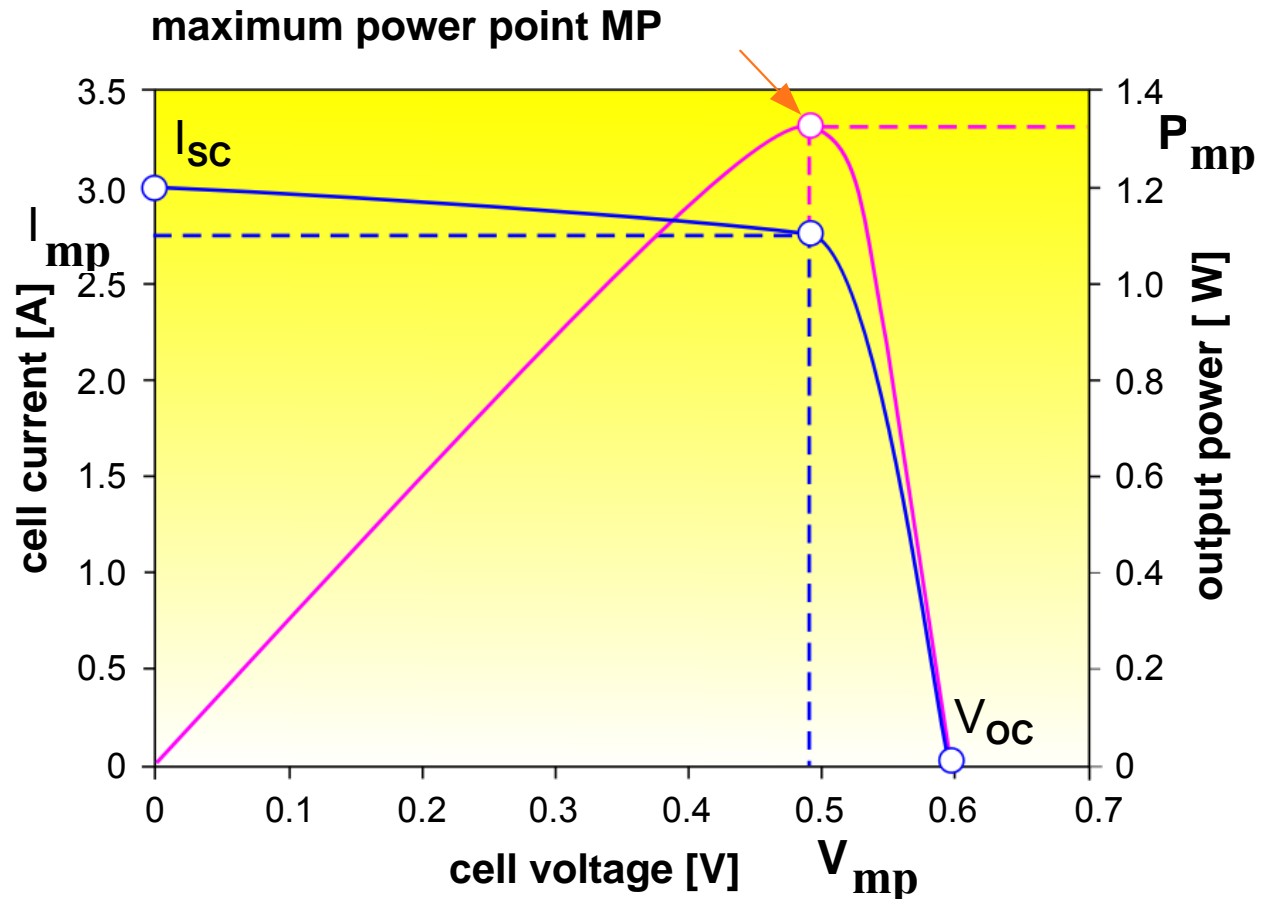

Figure 1. Current-Voltage and Power-Voltage Characteristics of a PV Cell

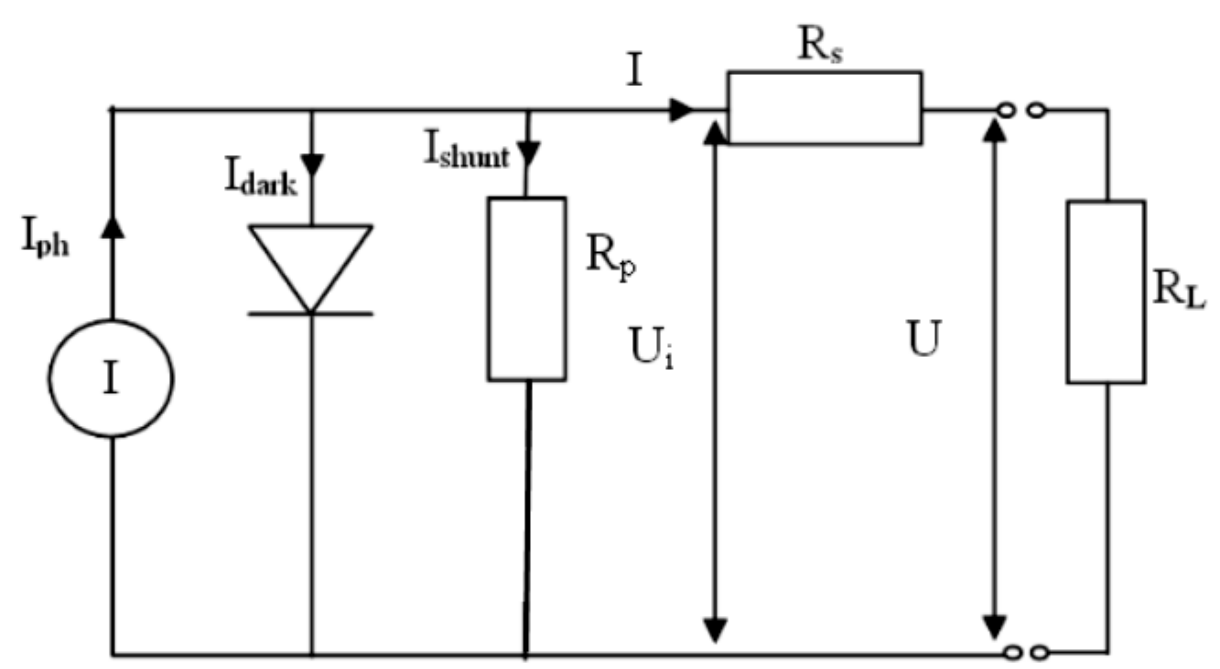

Figure 2. Equivalent circuit of the PV cell 


\subsection{PV Cells Modelling Results under Standard Test Conditions}

The electrical characteristics of polycrystalline solar cells of type Main Cell, with dimensions of $125 \times 125 \mathrm{~mm}$ and thickness of 300 $\mu m$, manufactured by RWE SCHOTT Solar have been modelled under standard test conditions (STC) and the following input data:

$$
\begin{array}{ll}
\mathrm{I}_{\mathrm{ph}}=5,13[\mathrm{~A}] & \mathrm{I}_{\mathrm{s}}=1,90 \cdot 10^{-10}[\mathrm{~A}] \\
\mathrm{R}_{\mathrm{s}}=0,012[\Omega] & \mathrm{R}_{\mathrm{p}}=27[\Omega] \\
\mathrm{U}=0,0,005 \ldots 0,617[\mathrm{~V}] & \mathrm{U}_{\mathrm{t}}=25,7 \cdot 10^{-3}[\mathrm{~V}] \\
\mathrm{m}=1 . &
\end{array}
$$

The following values have been obtained for the major electric cell parameters during modelling: $I_{m p}=4,87[\mathrm{~A}], U_{m p}=0,471[\mathrm{~V}], I_{s c}=5,13[\mathrm{~A}], U_{o c}=$ $0,53[V]$, and for the fill factor $-F F=0,85$. The graphic results from modelling are presented in Figure 3.

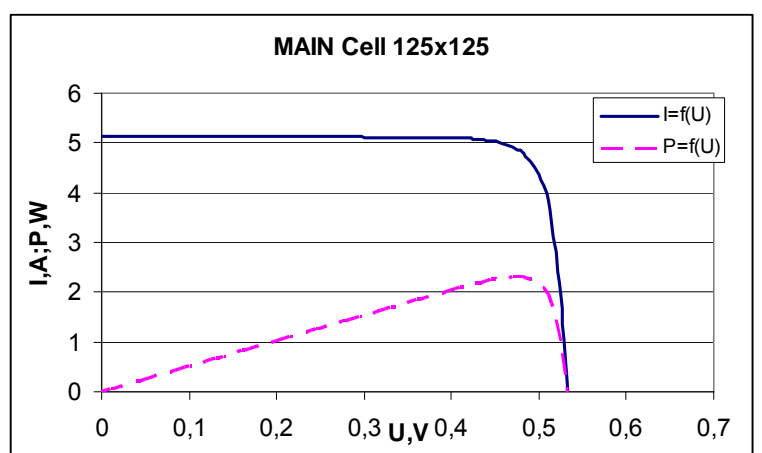

Figure 3. I-V and P-V Modelled Characteristics of $125 x$ 125 mm Main Cell under STC

The current-voltage characteristics of $125 \mathrm{x}$ $125 \mathrm{~mm}$ Main Cell from the model and STC catalogue have been shown in Figure 4 to evaluate the model used. It can be seen that the maximum difference is obtained in the area of the maximum power point, which results in insignificant increase in the fill factor FF, calculated during modelling. For the horizontal section and for the section in the proximity of the open-circuit voltage $U_{o c}$ of the current-voltage characteristic, the accuracy does not differ from the accuracy of the characteristic and its parameters given in the company catalogue: $3 \%$ for $I_{s c}$ and $2 \%$ for $U_{o c}$.

\subsection{Electrical Characteristics Modelling of Shaded PV Cells}

The generated current, i.e. power, respectively, is in direct relation with solar radiation.
When the solar cell or part of it is shaded, its current-voltage characteristic changes [2]. This effect is described mathematically by the so called shading factor $S_{s h}$ :

$S_{s h}=1-\frac{\bar{E}}{E_{0}}$

where:

$\bar{E}$ is the average value of solar radiation falling on the shaded solar cell;

$E_{0}$ is the value of solar radiation falling on the nonshaded solar cell.

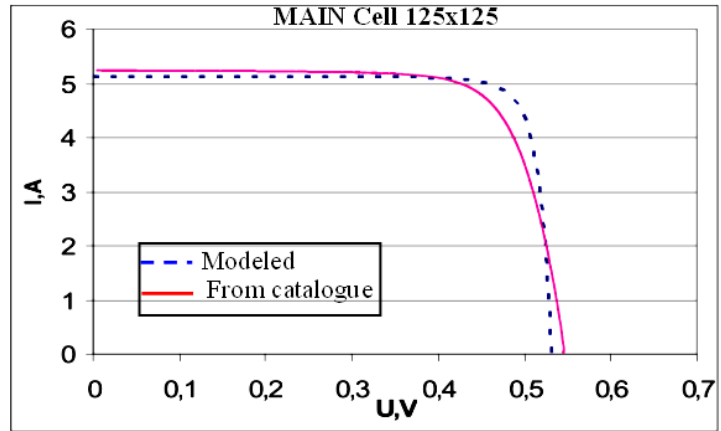

Figure 4. Comparison of Modelled characteristics to the Catalogue Current-Voltage Characteristics of $125 \times 125$ mm Main Cell under STC

If we assume that the photocurrent $I_{p h}$ of the PV cell is approximately equal to its short-circuit current $I_{s c}$ :

$I_{s c}=I_{s c 0}\left(1-S_{s h}\right)$,

then, taking into account that $I_{s c 0}=C_{0} E$, the equality obtained for photocurrent is:

$I_{p h}=C_{0} \bar{E}$

where:

$\mathrm{I}_{\mathrm{sc} 0}$ is the short-circuit current of the non-shaded cell; $\mathrm{C}_{0}$ is the conversion coefficient [A. $\mathrm{m}^{2} / \mathrm{W}$ ].

Then taking into account the shading factor $S_{s h}$, the expression (3) in Mathcad takes the form:

$$
\begin{aligned}
I\left(U, S_{s h}\right)= & \frac{\left\lfloor-R_{s} U-\left(A\left(U, S_{s h}\right)\right) \exp \left(A\left(U, S_{s h}\right)\right) m U_{t} R_{p}\right\rfloor}{\left(R_{p}+R_{s}\right) R_{s}} \\
& -\frac{\left[\left(A\left(U, S_{s h}\right)\right) \exp \left(A\left(U, S_{s h}\right)\right) m U_{t} R_{s}\right]}{\left(R_{p}+R_{s}\right) R_{s}} \\
& +\frac{\left\lfloor R_{s} I_{p h}\left(S_{s h}\right) R_{p}+R_{s} I_{s} R_{p}\right\rfloor}{\left(R_{p}+R_{s}\right) R_{s}}
\end{aligned}
$$

The current-voltage and power-voltage characteristics of the PV cell of type Main Cell 125 $\mathrm{x} 125 \mathrm{~mm}$ at $25^{\circ} \mathrm{C}$ (STC) and different shading rate: $0 \%$ (STC), $20 \%, 40 \%, 60 \%$ и $80 \%$, are shown in Figs. 5 and 6, respectively. 


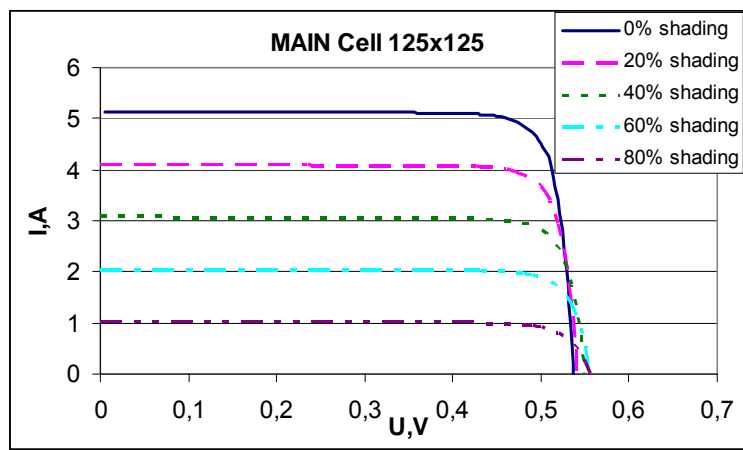

Figure 5. Modelled Current-Voltage Characteristics of $125 \times 125$ mm Main Cell under different shading

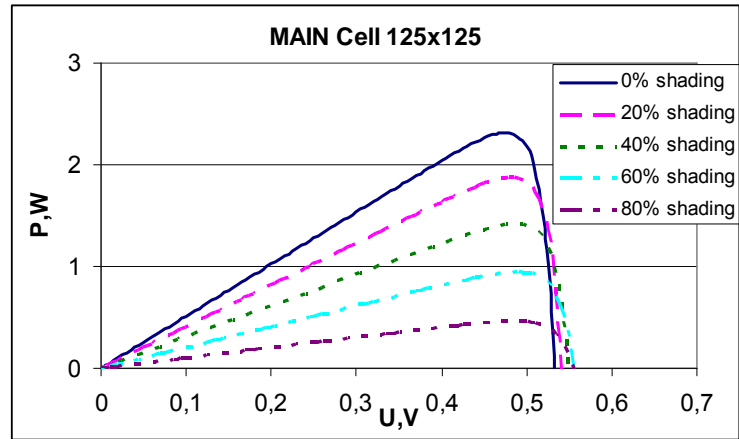

Figure 6. Modelled Power-Voltage Characteristics of $125 \times 125 \mathrm{~mm}$ Main Cell under different shading

\subsection{Influence of Temperature on Electrical Characteristics of PV Cells}

The following relations [3] have been used to estimate the impact of temperature on PV cell electrical characteristics:

$$
\begin{aligned}
& I_{p h, \text { new }}=I_{p h}\left[1+5,1010^{-4}\left(T_{\text {new }}-25\right)\right] \\
& I_{s, \text { new }}=I_{s} \exp \left[0,0967\left(T_{\text {new }}-25\right)\right] \\
& R_{s, \text { new }}=R_{s}\left[1+3,37 \cdot 10^{-3}\left(T_{\text {new }}-25\right)+9,71 \cdot 10^{-5}\left(T_{\text {new }}-25\right)^{2}\right] \\
& R_{p, \text { new }}=\frac{R_{p}}{1+5,80 \cdot 10^{-3}\left(T_{\text {new }}-25\right)-1,61 \cdot 10^{-4}\left(T_{\text {new }}-25\right)^{2}}
\end{aligned}
$$

Figure 7 and Figure 8 show the currentvoltage and power-voltage characteristics of the PV cell of type Main Cell 125 x $125 \mathrm{~mm}$, respectively, at various temperatures: $-5^{0} \mathrm{C},+50^{\circ} \mathrm{C}$ и $25^{\circ} \mathrm{C}$ and solar radiation in compliance with STC $-1000 \mathrm{~W} / \mathrm{m}^{2}$. The curves confirm that the temperature change is more significant in the area of the open-circuit voltage $U_{o c}$, which falls when temperature rises.

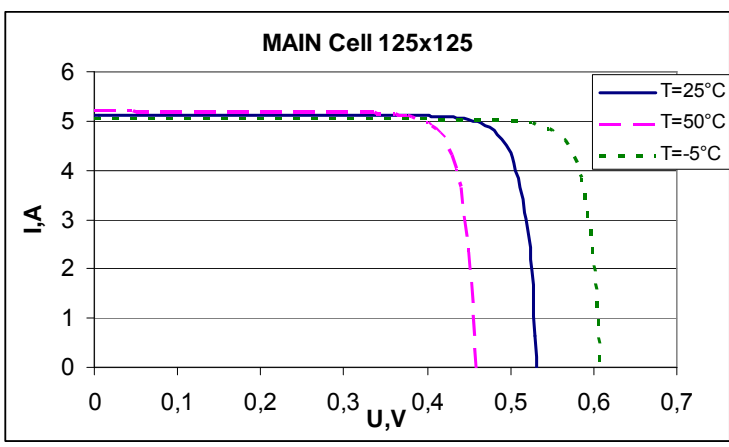

Figure 7. Modelled Current-Voltage Characteristics of $125 \times 125 \mathrm{~mm}$ Main Cell at different temperatures

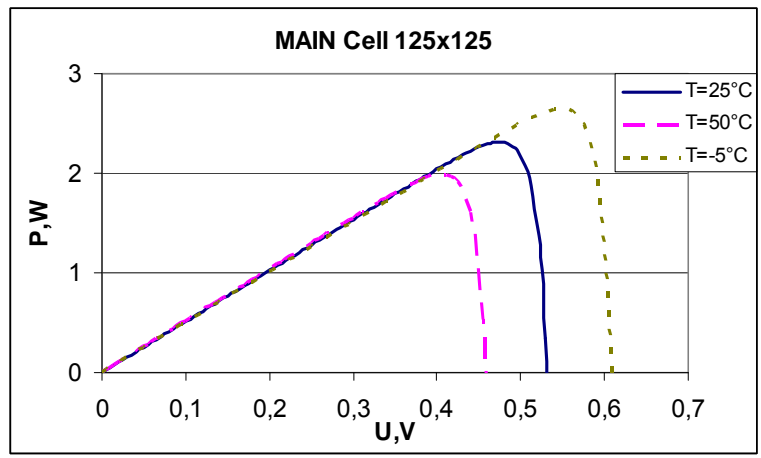

Figure 8. Modelled Power-Voltage Characteristics of 125 $x 125 \mathrm{~mm}$ Main Cell at different temperatures

\section{PV MODULES MODELING}

\subsection{Modified PV Modules Model}

In order to implement the models described above, it is necessary to introduce the physical parameters of the photovoltaic cells and modules as input data; however, they are not always provided by the manufacturers. Therefore, a simplified model can be used with adequate accuracy, which needs fewer input data which are always provided by the manufacturers and are the key electrical parameters of PV cells and modules: $I_{m p}, U_{m p}, I_{s c}, U_{o c}$. The principal equation for this model is [4]:

$I(U)=I_{s c}\left[1-C_{3}\left(\exp \left(C_{4} U^{n}\right)-1\right)\right]$,

where:

$\mathrm{C}_{3}=0,01175$

$C_{4}=\frac{C_{6}}{U_{o c}{ }^{m}}$

$C_{5}=\ln \left[\frac{I_{s c}\left(1+C_{3}\right)-I_{m p}}{C_{3} \cdot I_{s c}}\right]$

$C_{6}=\ln \left(\frac{1+C_{3}}{C_{3}}\right)$ 


$$
n=\frac{\ln \left(\frac{C_{5}}{C_{6}}\right)}{\ln \left(\frac{U_{m p}}{U_{o c}}\right)} .
$$

\subsection{PV Modules Modelling Results under Standard Testing Conditions}

The model described is employed in studying the performance characteristics of PV module ASE250-DG-FT/MC, built of $120 \mathrm{PV}$ cells type Main Cell $125 \times 125 \mathrm{~mm}$, whose characteristics have been modelled above. The input data are the basic electrical parameters of the module, as follows: $I_{m p}=$ $4,6[\mathrm{~A}], U_{m p}=61,5[\mathrm{~V}], I_{s c}=5,15[\mathrm{~A}], U_{o c}=74[\mathrm{~V}]$.

The results obtained for current-voltage and power-voltage characteristics of $A S E-250-D G$ $F T / M C$ PV module are presented in Figure 9 and Figure 10, respectively. The fill factor is calculated to be: $F F=0,75$.

Figure 11 illustrates a comparison between the current-voltage characteristics of $A S E-250-D G$ $F T / M C$ PV module, obtained, respectively, in modelling and listed in the manufacturer's catalogue. In this case, in the maximum power point area both characteristics match best.

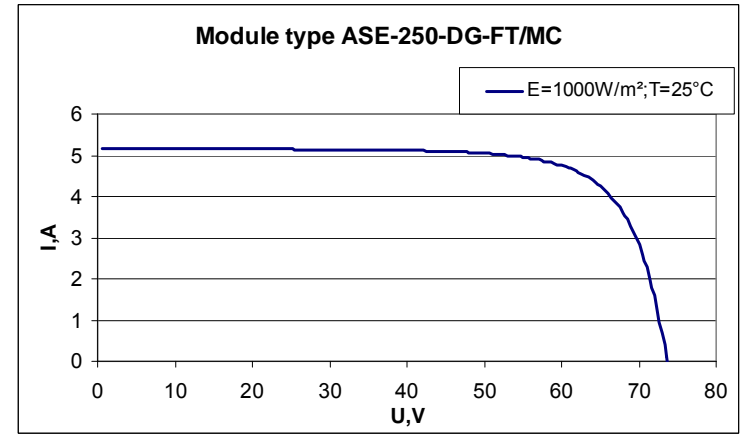

Figure 9. Modelled Current-Voltage Characteristics of ASE-250-DG-FT/MC PV Module under STC

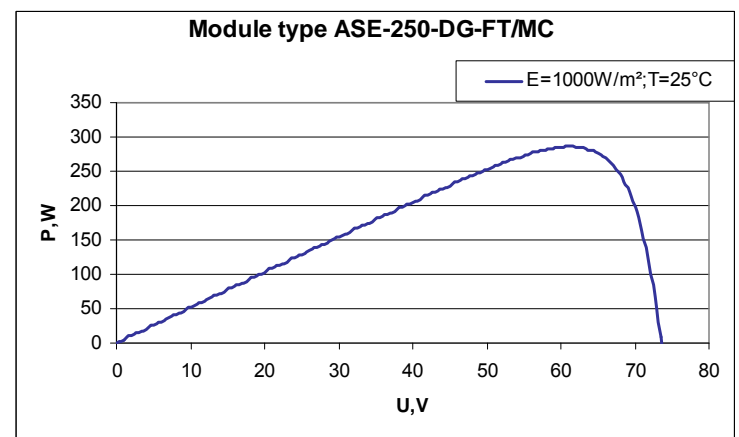

Figure 10. Modelled Power-Voltage Characteristics of ASE-250-DG-FT/MC PV Module under STC

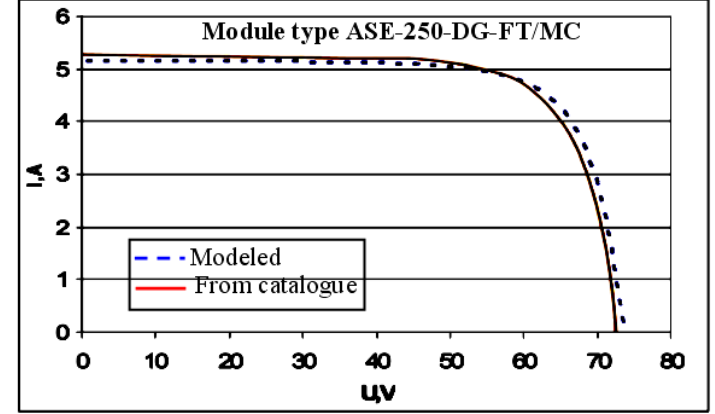

Figure 11. Comparison of Modelled characteristics to the Catalogue Current-Voltage Characteristics of ASE-250DG-FT/MC PV Module under STC

\subsection{Influence of Solar Radiation and Temperature on the Electrical Characteristics of PV Modules}

The solar radiation and temperature changes in the modified model are found by way of the following relations [5]:

$\Delta T=T-T_{\text {ref }}$

$\Delta I=\alpha\left(\frac{E}{E_{\text {ref }}}\right) \Delta T+\left(\frac{E}{E_{\text {ref }}}-1\right) I_{s c}$

$\Delta U=-\beta \Delta T-R_{s} \Delta I$

$U_{\text {new }}\left(U_{\text {ref }}\right)=U_{\text {ref }}+\Delta U$

$I_{\text {new }}\left(I_{\text {ref }}\right)=I_{\text {ref }}+\Delta I$,

where: $\alpha$ and $\beta$ are the temperature change coefficients, respectively, of temperature $\mathrm{T}$ and radiation $\mathrm{E}$.

These temperature coefficients for the studied module type ASE-250-DG-FT/MC are, $\alpha=$ $0,00515\left[\mathrm{~A} /{ }^{0} \mathrm{C}\right]$ and $\beta=0,28\left[\mathrm{~V} /{ }^{0} \mathrm{C}\right]$, and $\mathrm{R}_{\mathrm{s}}=1,5[\Omega]$, respectively.

The effect of solar radiation on currentvoltage and power-voltage characteristics of $A S E$ 250-DG-FT/MC PV module is shown in Fig.12 and Figure 13, respectively. Modelling has been performed at temperature $\mathrm{T}_{\text {ref }}=25\left[{ }^{0} \mathrm{C}\right](\mathrm{STC}), \mathrm{U}_{\text {ref }}=$ $0,0,01 \ldots 62[\mathrm{~V}]$ and solar radiation $1000\left[\mathrm{~W} / \mathrm{m}^{2}\right]$ (STC), $800\left[\mathrm{~W} / \mathrm{m}^{2}\right]$ and $600\left[\mathrm{~W} / \mathrm{m}^{2}\right]$.

The effect of temperature on current-voltage and power-voltage characteristics of $A S E-250-D G$ $F T / M C$ PV module is shown in Figs. 14 and 15, respectively. Modelling has been performed in solar radiation $\mathrm{E}_{\mathrm{ref}}=1000\left[\mathrm{~W} / \mathrm{m}^{2}\right]$, in conformity with STC, $\mathrm{U}_{\text {ref }}=0,0,01 \ldots 62[\mathrm{~V}]$ at temperatures: $25\left[{ }^{0} \mathrm{C}\right]$ (STC), $70\left[{ }^{0} \mathrm{C}\right]$ and $-20\left[{ }^{0} \mathrm{C}\right]$. In this case the effect of 
temperature on the characteristics in the open-circuit voltage area $U_{o c}$ is less significant.

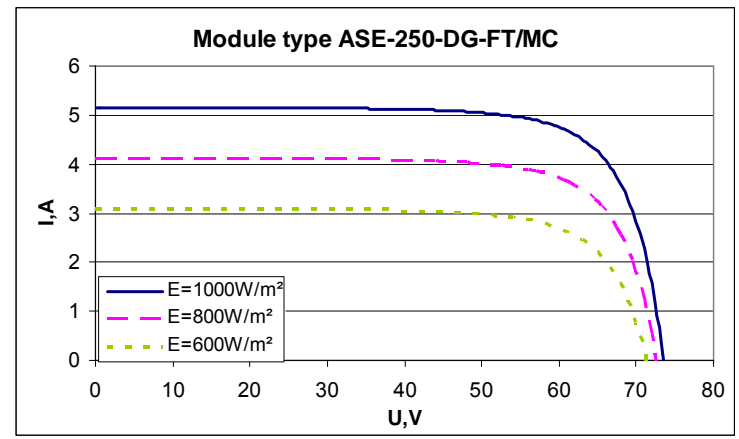

Figure 12. Modelled Current-Voltage Characteristics of Module Type ASE-250-DG-FT/MC under Different Solar Radiation

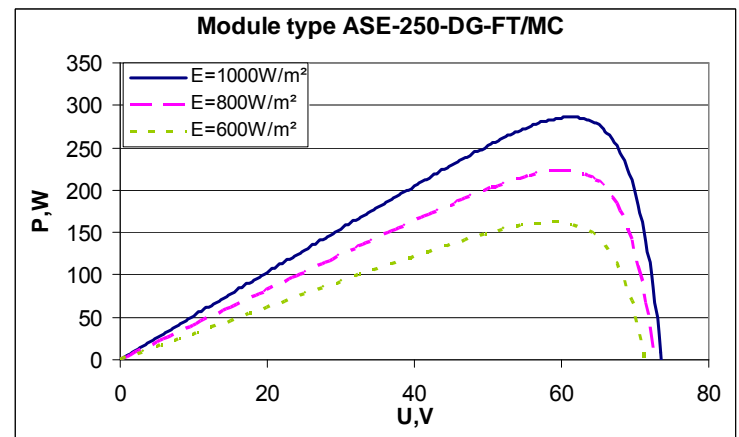

Figure 13. Modelled Power-Voltage Characteristics of Module Type ASE-250-DG-FT/MC under Different Solar Radiation

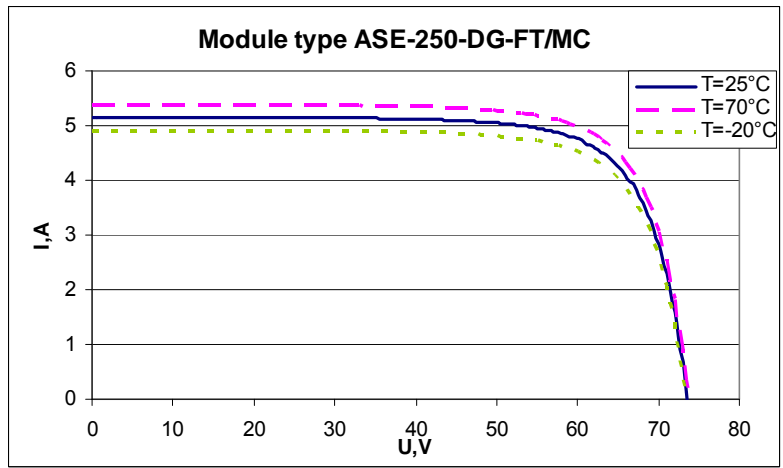

Figure 14. Modelled Current-Voltage Characteristics of Module Type ASE-250-DG-FT/MC at Different

Temperatures

3.4. Comparison of Modelled and Measured Electrical Characteristics of PV Modules

A comparison between experimentally taken and modelled current-voltage and power-voltage characteristics of the solar module IBC 80 can be made on the basis of Figs. 16 and 17, respectively.
The ratings of the IBC 80 module of the stand-alone PV system operating in the Technical University of Gabrovo are as follows: $\mathrm{P}_{\text {nom }}=80,0$ [W], $\mathrm{I}_{\mathrm{sc}}=5,08$ $[\mathrm{A}], \mathrm{U}_{\mathrm{oc}}=21,0[\mathrm{~V}], \mathrm{I}_{\mathrm{mp}}=4,71[\mathrm{~A}], \mathrm{U}_{\mathrm{mp}}=17,0[\mathrm{~V}]$. The calculated fill factor for IBC 80 module is 0,75 . The greater difference between the measured and modelled characteristics is due to the fact that measurements have been taken in real outdoor conditions, where solar radiation and temperature cannot be kept constant, corresponding to STC.

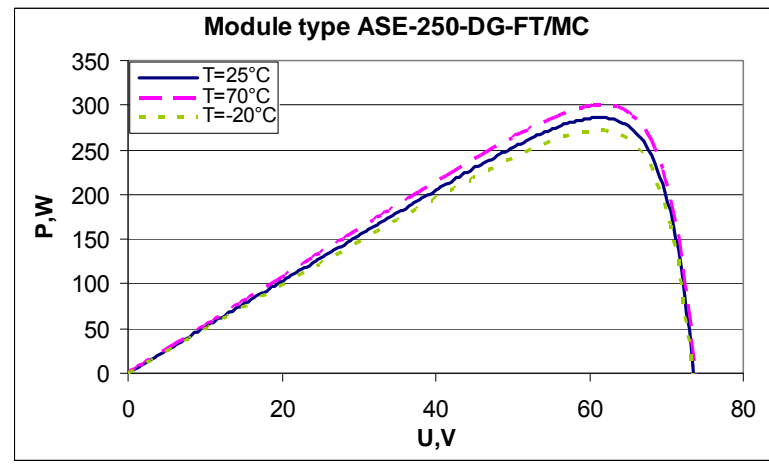

Figure 15. Modelled Power-Voltage Characteristics of Module Type ASE-250-DG-FT/MC at Different Temperatures

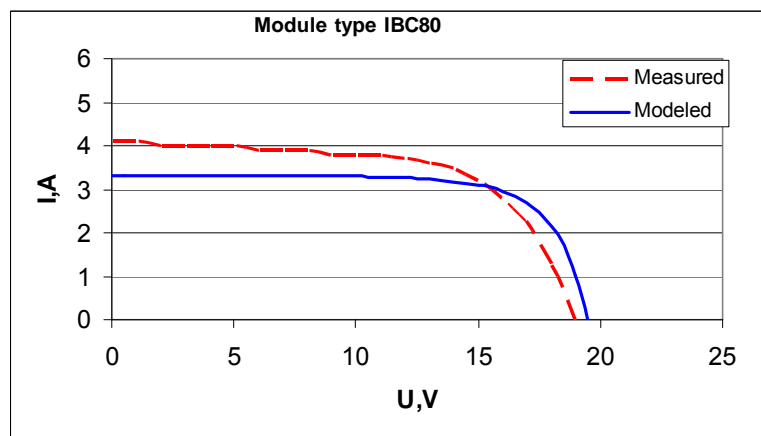

Figure 16. Modelled and Measured Current-Voltage Characteristics of IBC80 module type

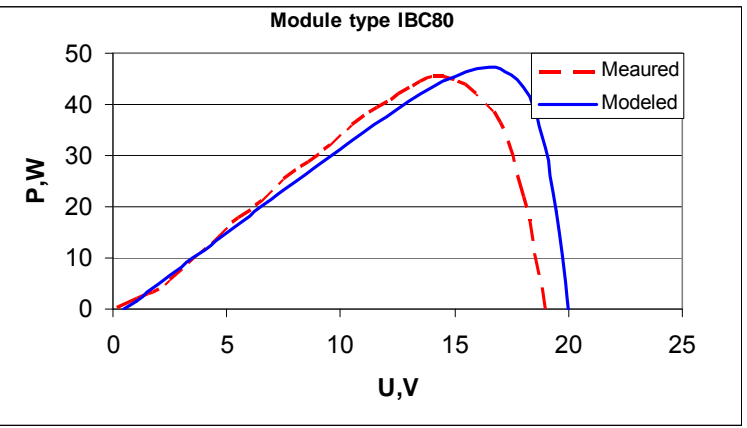

Figure 17. Modelled and Measured Power-Voltage Characteristics of IBC 80 module type 


\section{CONCLUSION}

The employment of classical and modified single-diode models for modelling the electrical characteristics of PV cells and PV modules, respectively, has been shown. Modelling has been performed both under standard test conditions, and with changes in temperature, solar radiation and shading. The model characteristics obtained reflect exactly the effect of these parameters. When the classical single-diode model was used a larger inaccuracy appears in the maximum power point area, than when using the modified one. The key electrical parameters of the PV cells studied, as well as the fill factor of the PV cells and PV modules modelled have been determined.

\section{REFERENCES}

[1] F. Iannone, G. Noviello, A. Sarno, Monte Carlo Techniques to Analyse the Electrical
Mismatch Losses in Large-Scale Photovoltaic Generators, Solar Energy, 62 (1998) 85-92.

[2] Q. Folker, R. Hanitsch, Numerical Simulation of Current-Voltage Characteristics of Photovoltaic Systems with Shaded Solar Cells, Solar Energy, 56-6 (1996) 513-520.

[3] Ts. Izumi, K. Nozaki, K. Sakuta, T. Oshiro, K. Korukawa, Simulation Results of StandAlone PV System under Various Load Conditions, $2^{\text {nd }}$ World Conference and Exhibition on Photovoltaic Solar Energy Conversion (6-9 July), Viena, Austria 1998.

[4] M. S. Ziyada, B. Borowy, A. Amin, Photovoltaic Module-Site Matching Based on the Capacity Factor, IEEE Transactions on Energy Conversion, 10-2 (1995) 326-332.

[5] R. Lamoureux, D. Sadarnak, N. Buchheit, Estimated Energy Gain Provided by an MPPT to Stand-Alone Photovoltaic System, 2nd World Conference and Exhibition on Photovoltaic Solar Energy Conversion (6-9 July), Vienna, Austria 1998.

$\operatorname{son}$

\section{МОДЕЛОВАЊЕ ЕЛЕКТРИЧНИХ КАРАКТЕРИСТИКА ФОТОНАПОНСКИХ НАПАЈАЮА ИЗВОРА}

Сажетак: Фотонапонски (ФН) генератори главни су елемент ФН електросистема; карактерише их низак коефицијент конверзије. Ово оправдава потребу за изучавањем струјно-напонских и снага-напонске карактеристике ФН извора како би се добила максимална излазна снага када дође до промјена и у самим модулима и у окружењу у којем раде. У овом раду коришћени су класични и модификовани модели са једном диодом за моделовање електричних карактеристика ФН ћелија и модула. За моделовање је коришћен Mathcad софтверски пакет. Изучавани су утицај сунчевог зрачења, температуре и засјењавања на електричне карактеристике и на ефикасност ФН ћелија и модула. Copyright (C) 2006 IFAC

Кључне ријечи: електричне карактеристике, модел са једном диодом, моделовање, ефикасност. 